\title{
Determinants of Attitude and Intention towards Adoption of Islamic Finance among Small Businessmen of Rawalpindi and Islamabad
}

\author{
Ali Imran Shaikh*, Faiz Ur Rahim \& Tehseen Taimoor \\ School of Islamic Banking and Finance, International Institute of Islamic Economics, International Islamic \\ University, Islamabad, Pakistan.
}

\begin{abstract}
Halal and Islamic Finance business sectors are Shariah-compliant and the values, principles and market they share with each other are very similar. In spite of these significant similarities, the connection between Halal sectors and Islamic finance is not very healthy. We can quote an example of Malaysia here, where this poor connection is comprehendible as the people from Halal industry adopt Islamic Financing at a very low rate. In order to become a real Halal business operator, the venture must be conscious about the adequate and halal means of financing as well apart only focusing upon the Halal production. Nevertheless, this phenomenon does not seem to be properly addressed. In order words, we can say the Holistic Halal concept should be adopted by mandatory integration of the Halal production with Islamic financing. This research aims to find the determinants the attitude and intention towards adoption of Islamic finance among 'Small Businessmen' through survey instruments.
\end{abstract}

Keywords: Islamic Finance, Attitude Towards Islamic Finance, Small Business, Halal Business, Halal Industry.

\section{Introduction}

Islamic Finance and Halal businesses share very similar set of values, principles and market. The values of both are based on the Islamic values, the equity, justice and other pillars of Shariah teachings. Islamic banking is devoted for a fair, balanced and just society according to the directions of Islamic economics (Mirakhor, 2011). That is why they can be considered very natural partners to each other. Their values and nature of practices are very widely acceptable all over the world and growing at a very fast pace as well. Islamic banking industry has proved to be one of the most rapid growing industries over the past three decades. It is spread to all parts of the world and embraced by both Muslims and non-Muslims alike (Iqbal \& Molyneux., 2005). In spite of similarities with each other, the connection and interaction between the two industries are very insignificant. Both are developing independently. The point is, despite having so many similarities, why they still resist each other. If they complement each other, it will also expedite their individual pace of progress. Due to the extent of the similarities between the two, they can be explained like twins separated at birth. A study conducted in Malaysia where $87.3 \%$ of the Muslims population was nonusers of Islamic Finance, which is an alarming figure as Malaysia, is a country with mainly Muslim residents in it (Jalaluddin, 1999).

For the last many decades, Islamic finance has emerged to be a disciplined and global brand. 
On the other side, Halal markets were flourished in past ten years but in segments (Halal Focus, 2011). In addition to their fragmentation, they were less structured as well. Likewise, the scenario in Pakistan is also facing disintegration between halal businesses and Islamic banking. State Bank issued its Islamic banking policy first time in 2001 and now it is about two decades but still the market share recorded as in June 2019 survey or data is 15.6\% (State Bank of Pakistan, 2019). Nevertheless, this is an overall market share, which involves usage of other segments as well but still this is low as compared to what it is supposed to be in an environment that is highly conducive for it. This issue lacks the study based on empirical examination and evidence. It seems a high time for researchers to scrutinize the attitude of halal businessmen towards Islamic financing in Pakistan. This study is an endeavour to know the non-user businessmen's attitude and intention towards adoption of Islamic financing in Pakistan.

Bananuka et al. (2020) has emphasized on one of the components of attitude that is religiosity and religiosity preferences. However, attitude still has many other components which eventually affect the intention. The methodology used here is a different one as well. In my study I am using SEM to study the attitude factors as a whole to affect the behavioural intention. Raza et al. (2019) has a focus on Kafala (Islamic Insurance) with Theory of Perceived Behaviour (TPB) and they have opted for the very similar model, which I have used in my study. However, they have not focused on the other components of Islamic finance adoption with the focus on the non-users. Although the work has been done on some components yet the overall study of Islamic finance with the TPB has not been addressed yet. Work has been done on takaful but not on non-users of Islamic finance in this study. Sattar et al. (2020) is very similar to that of mine. The inspiration of this study is the same base paper. The place of this research conducted was Morocco. I have intended to study this in Pakistan due to very similar demographic conditions. Janah et al. (2020) has focused on use of Islamic banking in Indonesia by their Islamic leaders. In my study I intend to replicate many iterations in the studies with some alteration in the geographic group. The endeavour which I have intend to do has not been done before that focuses on non-users of Islamic finance in the twin cities of Pakistan. To make the research more effective we were precise in our research with the under usage of small businesses in 'Twin Cities of Pakistan'. In order to become truly Halal business operator, every pillar associated with the business must comply with Islamic teachings. Therefore, Halal businesses must be financed with the Islamic way of financing (Ghani, 2013). Nevertheless, the situation prevailing in Pakistan is contrary. There is a lack of empirical evidence on this issue in Pakistan. Therefore, I believe this will add value by unravelling the attitudinal factors of non-user businesses to adopt Islamic Finance. The research objectives are to examine the most effective latent variable of Attitude and Intention towards non-users of Islamic banking. In this research endeavour we will try to complete our research objectives through structural equation modelling (SEM) by applying theory of perceived behaviour.

\section{Literature Review}

There were many past studies that has an emphasis on the Islamic finance among individual customers in terms of their attitude. Very few efforts are made yet to scrutinize and study this in terms of business firm's perspective. Jalaluddin (1999), Ahmad and Haron (2002), Edris (1997) and Gait and Worthington $(2008$; 2009) were people who endeavoured to study business firms' segment. The initiative was taken by Edris (1997) through the Kuwait based study on determinants of bank selection regarding business firms. They have selected dual banking sample size of 304 business firms. This research concluded that businesses in Kuwait favours commercial banking over Islamic banks. Despite being a dominated religion in Kuwait, Islamic 
factors motivate the interest of individual customers towards Islamic banks. It shows the religiosity is not the sole bank selection criteria in the country. A research study done by Jalaluddin (1999) based on Australia selected the sample size of 385 and studied the attitudes of small businesses towards the profit or loss sharing method of finance. The results suggested that risk sharing level between lenders and borrowers, business support, the factors of default risk in conventional banking system like rate of interest, expected rate of return, the link of profitability with cost of borrowing were the reasons they get inclined to the system of profit or loss sharing. The factors that cause discouragement to apply profit and loss sharing method were the cost of borrowing and its terms and conditions, extent of management intervention.

Ahmed and Haroon (2002) conducted the research in Malaysia by taking the sample of 45 business firms that are Islamic banking customers. This study was done to identify their perception towards Islamic finance and the results concluded very low usage of Islamic banking products. As a matter of fact, many targeted respondents have adopted Islamic banking for less than 5 years and it was established for nearly 15 years. Non-Muslims were 65 percent of the total population. They have lower amount of knowledge regarding the system and principles of Islamic Banking especially in comprehending share of profit concepts. Another study regarding attitude towards Islamic finance methods was conducted by Gait and Worthington (2009) in Libya with 296 business firms. Despite lack of formal practice of Islamic Financial Institutions in the country, the results showed that 72.3 of the corporate customers of Islamic banking are interested to use Islamic finance. The primary driving factor for these corporate firms to incline towards Islamic finance is religiosity, subsequently other factors were unique services, profitability, and business support. The non-users have the opinion that there is no difference between the two banking systems and Islamic banking is the more expensive option. The literature has seldomly examined the attitude towards Islamic finance through a research model. Very few studies have adopted theoretical framework of TPB (Theory of Perceived behaviours) for researches and in Pakistan this is still due.

The research conducted in Pakistan Butt and Mahmood (2011) has a motive to identify the obstacles perceived and faced by the users and non-users of Islamic Banking when they intend to select the Islamic Banking. The research question is that what hurdles a person may face who wants to choose Islamic banking? This study has the primary data sources from two types of banking customers, from both conventional and Islamic banks. That means both the users and non-users of Islamic Banking. This is a qualitative research which involves the interviews with IB managers and the two data sources. So, the primary data collected is from both the supplier of services and consumer of service as well. The research is done through designed questionnaire that receive 109 responses in total. The data is then used in hypothesis testing, cluster analysis and factor analysis the research has some interesting findings. It includes the perception of people that the system of Islamic banking does not truly adhere to the Islamic principles. The branches located are not easy to access by the potential customers. Moreover, the network of these branches is not wide as well. This study gives us the other method of viewing the bank selection criteria i.e., the hindrances faced or at least perceived by the potential customer. The aforementioned method is very helpful as it relates and measures the faced obstacles with Islamic Banking especially if compared with the already available literature to the subject. Pakistan is the region where still the operations of Islamic banking is in the development stage. It adds value to the limited literature about consumer attitude towards Islamic banking in Pakistan. The study conducted in Pakistan by Lee and Ullah (2011) was to 
find and examine the factors that patronize the customers towards Islamic bank selection decision in Pakistan.

Islamic banking customer is considered to be very cautious about the Shariah legitimacy of the offered products by the IBs and also the risk of violation of Islamic principles in case of withdrawals and deposits in these banks. This paper intends to examine this general perception. Data collected from 357 customers and based on the data collected, this paper uses descriptive statistics and cross tabulation analysis. The findings were revealed to be same according to the prevailing perception that customers anticipate and highly demand the Shariah legitimacy of the products offered by IBs. Nevertheless, the IBs are found to violate the Shariah teachings which make the customers interested to switch their banks. In addition to the above, it was also found that products' and services' adherence to Shariah principles is not the sole criteria here. Customers also expect the banks to offer convenience, ensure safety of their capital, provide up to date advance technological services as well to them. The anticipation of customers is very important especially for the newly opening Islamic Banks and Islamic 3Financial Institutions. In Pakistan. In addition to that, the cutthroat competition also requires them to become up to date and competitive with their counterparts. This is a significant contribution to the selection of Islamic banks criteria by the customers. The factors which attract the customers towards conventional banking and the Shariah legitimacy of the products have been exposed in this study. This paper contributes with very practical implications pertains to both regulators and owners (Lee \& Ullah, 2011).

Summarizing these studies, we can see the study of nonusers with respect to their attitude and intention towards Islamic financial adoption in many Pakistani regions is still due. Especially examining the urban cities can be helpful in knowing the non adopters of Islamic banking so their anticipations can be addressed in order to evolve Islamic banking products further.

\section{Theoretical Framework}

In this research, 'Theory of Planned Behaviour' is used as a theoretical framework. TPB is used to explain the decision-making process. This theory is proposed by Ajzen (1991) TPB came after many refined endeavours of 'Theory of Reasoned Action' TRA. According to this theory, the behaviours are appraised through Attitude, Subjective norms and Perceived Behaviour Control. Many studies have been done till now using Theory of Planned Behaviour as base. These studies include Jaffar and Musa, (2016).

\section{Variable Description}

There are many independent and dependent variable in this model. The ultimate dependent variable is behavioural Intention which depends upon attitude, subjective norms and perceived behaviour control. This can be represented in an empirical way.

Behavioural Intention $=$ F (Attitude, Subjective Norms, Perceived Behaviour Control) .

Whereas, attitude has its own explanatory latent variables that are knowledge and awareness, business support, cost benefit, religious obligation and reputation. This can be represented as:

Attitude $=\mathrm{F}$ (Knowledge and Awareness, Business Support, Cost benefit, Religious Obligation, Reputation). 


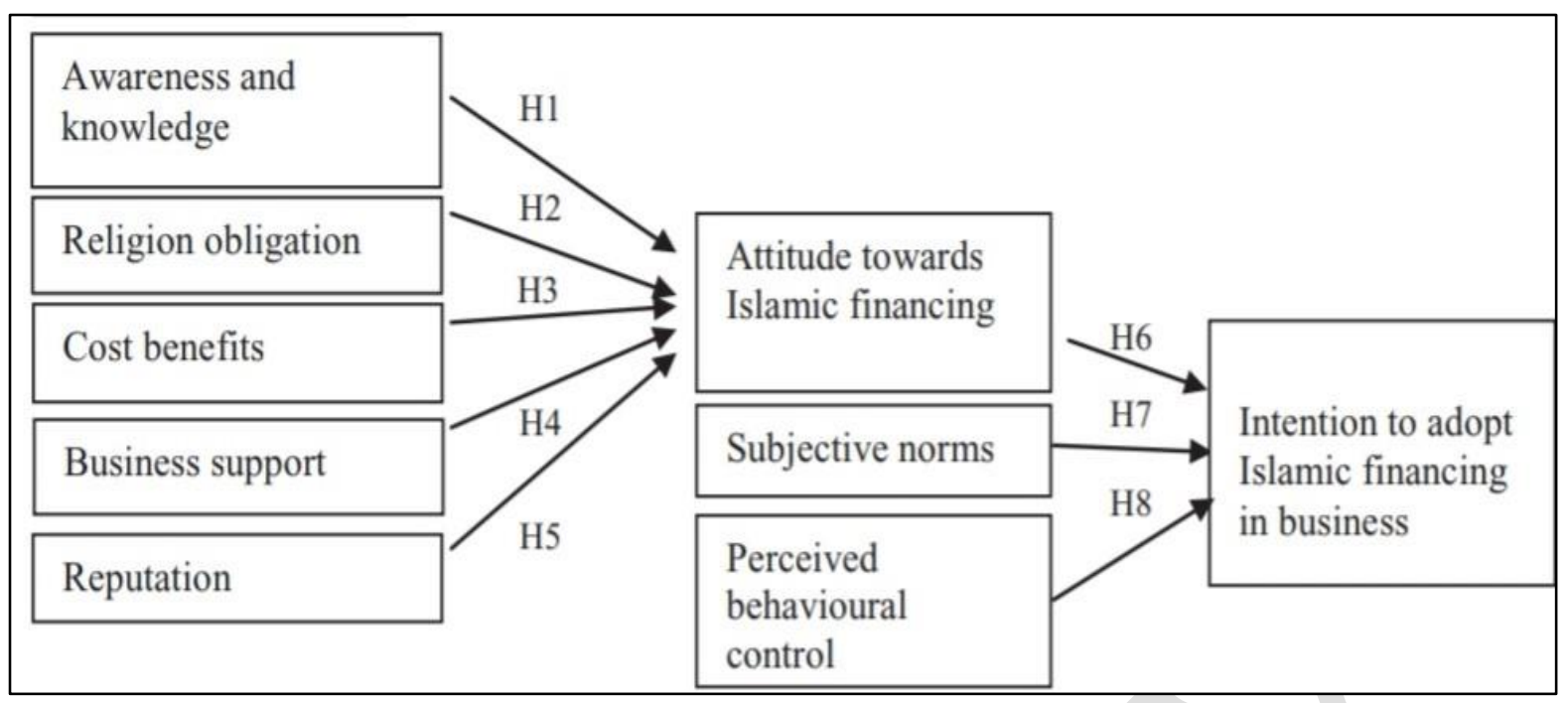

Figure 1: The conceptual framework is illustrated above which we can comprehend better when formulating hypothesis

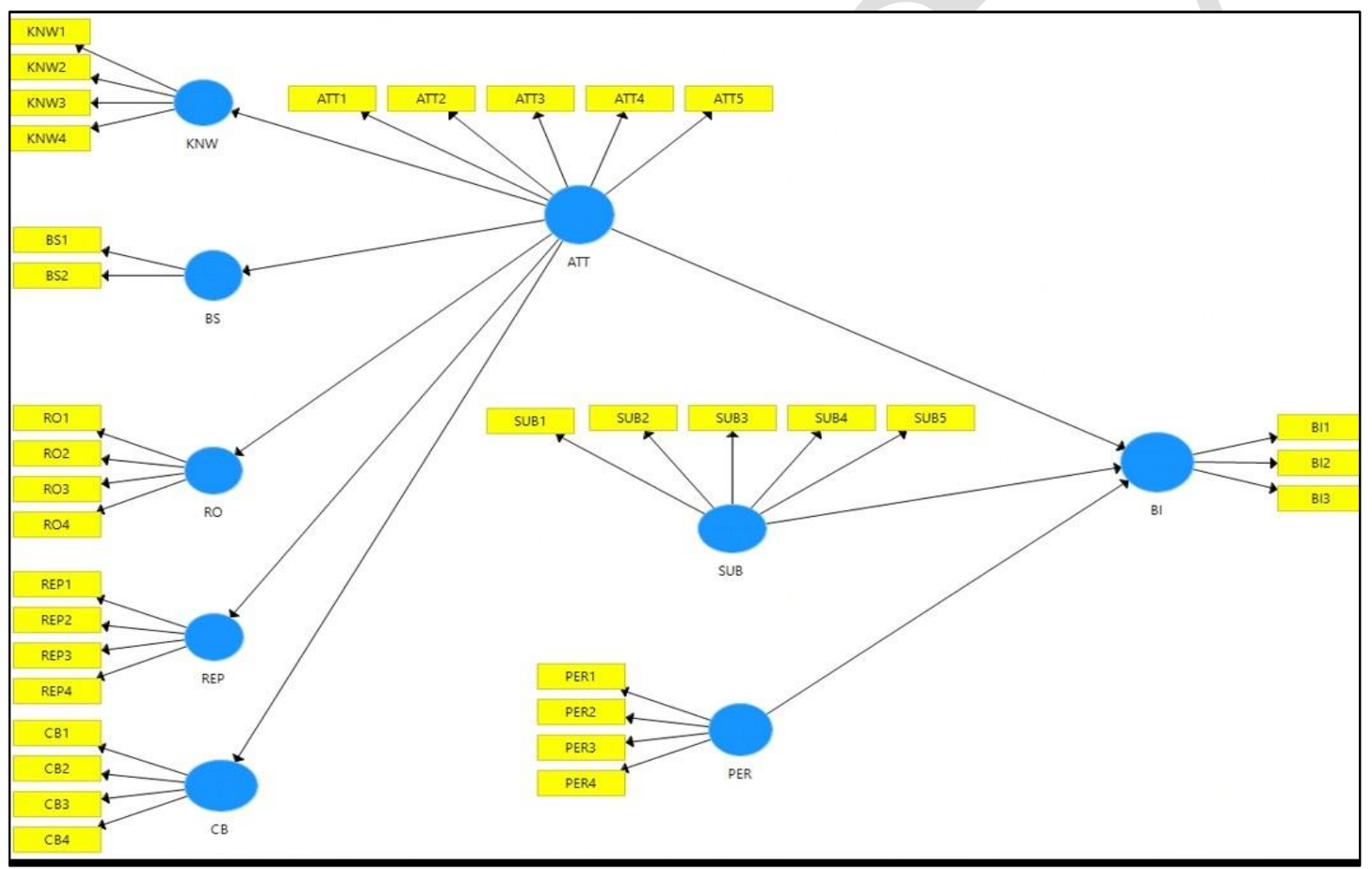

Figure 2: Extracted from PLS SEM and is based on this theoretical framework

KNW= Knowledge and Awareness

$\mathrm{BS}=$ Business Obligation

$\mathrm{RO}=$ Religious Obligation

$\mathrm{REP}=$ Perceived Behavioural Control

$\mathrm{ATT}=$ Attitude

$\mathrm{SUB}=$ Subjective Norms

$\mathrm{PER}=$ Perceived Behavioural Control

$\mathrm{BI}=$ Behavioural Intention 


\section{Hypothesis Development}

\subsection{Knowledge and Awareness}

These two words can be used in place of each other. Awareness can be defined as being conscious of objects, events, emotions, sensory patterns or thoughts. Whereas Knowledge can be defined as is information, skills and facts that can be achieved through education and experience. Knowing something or familiarity gained by education or experience is called Knowledge whereas the amount of perception, knowledge or realization related to a fact or situation is called awareness (Wirtz \& Matilla, 2003).

Hypothesis 1: "A positive relationship exists between awareness and knowledge."

\subsection{Religious Obligation}

An obligation is defined as a mandatory measure or action that someone is required to take. This action can be moral or legal. This concept of obligation can be extended to various other contexts, such as religious obligations, etiquette obligations and social obligations. As far as religious obligation is concerned, these are the religious requirements that must be fulfilled. An individual's choice or activities is affected by the role of religion. This concept is explained by Religious obligation (Amin et al., 2011). The appraisal of Religious obligation is also appraised on adherence to the fundamental Shariah principles. These principles include investment in Halal business, equal distribution of wellbeing and Riba-free status. This research propounds that the eminent adherence to Shariah principle, the more beneficial attitude is ensured.

Hypothesis 2: "A positive relationship exists between attitude and religion obligation."

\subsection{Cost Benefits}

Islamic methods of finance are possibly correlated to perceived cost benefits. Cost benefits is a systematic approach to measure the strengths and weaknesses. It includes cost benefits ratios. There are many factors used to measure cost benefits. According to Al-Ajmi et al. (2009) the factors that determine the cost benefits are availability of credit, lower charges of service, lower monthly payments, favourable terms, rate of return and product cost determine the cost benefits.

Hypothesis 3: "A positive relationship exists between attitude and cost benefits."

\subsection{Business Support}

Business support variables are measured by extent of support of Islamic financial Institutions in business innovation, expansion, efficiency, and management matters. (Gait and Worthington, 2009). There are different sections for Business support. First section related to financial support for example grants, loans and working capital. The remaining section consists of non-financial support services like management, advisory, research and development. (Yusoff \& Yacob, 2010).

Hypothesis 4: "A positive relationship exists between attitude and business support." 


\subsection{Reputation}

Reputation can be defined as opinions and beliefs generally expressed pertaining something or someone. The Reputation of an organizations is dependent upon its trustworthiness, social responsibility and reliability. (Fombrun, 1996). Social welfare responsibility comes under the umbrella of social responsibility. The research done before suggests that consumers' selection of banking is very much dependent upon the involvement of banks in social welfare responsibility. (Al-Ajmi et al., 2009; Dusuki \& Abdullah, 2007). Islamic banks should promote Islamic values by upholding social objectives to the customer (Dusuki, 2008). Derived from the defined variables above, we come up with the following hypothesis:

Hypothesis 5: "A positive relationship exists between attitude and reputation."

\subsection{Attitude towards Islamic Financing}

Favorable or unfavorable appraisal of the individual's behavior is referred as attitude towards the behavior. Fishbein et al., (1980). A research study conducted by Amin et al. (2011) revealed the positive relationship of intention and attitude pertaining to Islamic Personal Financing. This research examines attitude through latent variables i.e., knowledge and awareness, cost benefits, religious obligation, business support and reputation.

Hypothesis 6: "A positive relationship exists between intention to adopt Islamic financing in business and attitude."

\subsection{Subjective Norms}

A social pressure to fulfil or not to perform a given act or behaviour is defined as subjective norm. In this portion we have questions related to normative behaviour refers to conformity, for example in a certain event it may be generally perceived that people will be dressed up with 3 -piece suits and we cannot wear jeans or trousers. This is a behaviour that came out from norm invocation. This dressing up according to the occasion is an example invocation messages that enforces to perform a certain behaviour due the notions of social pressure. It has no direct punishment; it is a sense of intimidation from a society that pushes a person to follow certain behaviour and influencing the habits. As described by Fishbein et al. (1980), attitude towards the behaviour refers to the individual's favourable or unfavourable evaluations of the behaviour is defined by the attitude towards the behaviour. The research done by Amin et al. (2011) appraised attitude pertaining with Islamic financing from 5 determinants i.e., religion obligation, knowledge and awareness, cost benefits, reputation, and business support. Furthermore, the research ascertained that there is a direct connection of intention with the attitude to use Islamic personal financing. It also suggested that Islamic personal financing is directly affected by subjective norms. The brief definition of subjective norms by Ajzen (1991) is the perceived social pressures which effect behavioural intention of an individual. Subjective norms are regulated by the perceived social pressure from others for an individual to act in a definite approach and their inducement to comply with those people's perspective.

Hypothesis 7: "A positive relationship exists between intention to adopt Islamic financing in business and subjective norms." 


\subsection{Perceived Behavioural Control}

It indicates our perceptions of our own ability to perform certain act or behaviour. For example, 'It is my responsibility to switch off the lights before I sleep'. The way people perceive the possibility or level of difficulty in performing the behaviour of interest is called perceived behavioural control (Ajzen, 1991). The perceived behavioural control in this study propose that entrepreneurs are probable to endorse Islamic financing in business if they perceive they have command over the behaviour or are averted to assume Islamic finance in which they do not have any control. According to these, we bring forward the following hypothesis.

Hypothesis 8: "A positive relationship exists between intention to adopt Islamic financing in business and perceived behavioural control."

\subsection{Intention}

Intention can be explained as the intensity of endeavour that someone to commit a certain act or behaviour that is also attributed by the level of determination a person plans to utilize in order to perform the concerned behaviour. This research study is based upon (TRA) theory of reasoned action. This theory is used to deliver insights into the intention to adopt Islamic banking. As per Fishbein and Ajzen (1977) and Orobia et al. (2016), Theory of Reasoned Action is a theory, which presumes that individuals make logical and rational decisions that can also be called as intentions. It depicts that for every behaviour performed, there must be an intention to perform that behaviour. It indicates that the higher the behavioural intention is, the higher will be the likeliness of performing the concerned behaviour. The model Theory of Reasoned Action utilizes major two factors that play their part to behavioural intention. These factors are the attitude toward the subjective norm and behaviour. Other than TRA, the religious concern is also a factor that can impact the intention to adopt Islamic banking (Mokhlis, 2008; Alam et al., 2012). The phenomena of Intention to Islamic banking adoption can b illustrated in a better way by perceived and awareness benefits (Davis et al., 1989; Echchabi \& Aziz, 2012). Awareness defined by Jaffar and Musa (2014) as a condition of having or showing perception, realization or knowledge of a fact or situation. Perceived usefulness as per According to Davis et al. (1989), is a basic element of the (TAM) Technology Acceptance Model that is used to measure customers' behavioural intention. Perceived usefulness as explained by Davis et al. (1989) is an extent of believes a person possess that a system's usage will make them enjoy its perks and benefits.

\section{Research Methodology}

\subsection{Structural Equation Modelling (SEM)}

Structural Equation Modelling is based on the multivariate statistical analysis. This technique is used to study the structural relationships. This technique analyze the structural relationship between latent constructs and measured variables through amalgamation of multiple regression analysis and factor analysis.

\subsection{Confirmatory Factor Analysis (CFA)}

Confirmatory Factor Analyses is an integral part of SEM hence its incorporation in the methodology is inevitable. This analysis is done on the set of variables to verify their factor 
structure. It allows to test the relationship existence of observed variables and their respective latent constructs through hypothesis testing. As discussed above, the constructs are made according to Theory of Planned Behaviour TPB (Ajzen, 1991). The dependent variables for attitude are Religious obligation, knowledge and awareness, business support, cost benefits and reputations. Attitude with Subjective Norms and Perceived Behaviours will be an explanatory variable to attribute the ultimate dependent variable Behavioural Intention. The research tool for this research is Structural equation modelling in PLS SEM 3.

We have used convenient sampling and selected 300 small businesses as the adequate sample. There are three major portions of the questionnaire. Section-A contains the information about the respondents' attributes, the information of their businesses like number of employees, category of business. It also contains the demographic information of these businessmen. In Section-B, the questions are intended to determine the belief factors. These factors are religion obligation, business support, knowledge and awareness, reputation and cost benefits. In Section-C, the questions are pertaining to the essential constructs of TPB. These are attitude, subjective norms, perceived behavioural control and behavioural intention. These multi-item measures are evaluated by five-point scale system and are used to operationalize direct indication of attitude.

\subsection{Population}

The total population examined is small business holders of Twin Cities with at least one bank account in any conventional bank in Pakistan. This total business data is extracted from 'Chamber of Commerce'.

\subsection{Data Collection}

Research is conducted through field interview as the main source of data collection. Total 300 samples were collected from twin cities Rawalpindi and Islamabad using convenient sampling. Total number of businesses as per Chamber of Commerce is around 30,000. 1\% of this becomes 300. This research has also conducted a descriptive analysis to have better familiarity with the collected data through survey. At the next stage, a strong multiple variable technique is used to do analysis of this data through Structural Equation Modelling (SEM) and Confirmatory Factor Analysis (CFA). These techniques are used to test the link of hypothesis among constructs in order to know the significant determinants of intention and attitude towards Islamic finance adoption. These two analyses will be discussed in 'Results and Discussion'.

\section{Results and Analysis}

In the table-1, the result is provided for the descriptive analysis done on the gathered data. The table shows the non-users of the Islamic banks are very large in number for the Muslim potential users. 88 percent Muslims are not using the Islamic banking services in the Muslim majority country. 88 percent of Muslim found to be non-users and 78.6 percent were males. The age bracket of $31-40$ years old has the majority of non-users' respondents ( 26.33 percent). This is followed by non-users' 27 percent in the age group of 41-50 years. The annual sales turnover figure depicts 53.1 percent of the respondents that are non-users consists micro and small-sized enterprises. In fact, the results show a greater representation of micro-sized enterprises (39 percent) in the non-users where the business sales turnover reached less than 
Rupees 500,000.00 annually. The number of staffs has reinforced the domination of the smallsized enterprises (60 percent) with 5 to less than 50 employees while the micro-sized business constitutes 27.66 percent of the non-user's sample.

Anderson and Gerbing (1988) has suggested the two-step approach to Sem analysis. These two steps are. First step is Measurement model or CFA Confirmatory factor analysis and then Structural model (It discusses the tools that help to know the adequacy of that model). PLS SEM 3 is used for Confirmatory Factor Analysis (CFA). According to Montoya-Weiss and Calantone (1994), construct validity and reliability of the measurement scale could be assessed by CFA. It can demonstrate the reliability evaluation, unidimensional, convergent validity. The threshold value for standardized regression should be ranging above 0.7 to provide adequate unidimensionality. The construct indicators of internal consistency are reflected by Composite reliability (CR). The composite reliability scores should be more than the acceptable criteria of 0.7 that clearly shows that internal consistency is sufficient. The threshold value for standardized regression should be ranging above 0.7 to provide adequate uni-dimensionality. Measurement Fit Criteria is a measure of adequacy which involves Outer Loadings, Construct and Discriminant Validity. Outer Loadings of each factor should be around 0.7 in an ideal scenario but still 0.5 is acceptable if it is indispensable.

Cronbach's alpha is analyzed to double check the scale reliability. The value should range from 0.75 to 0.93 , exceeding the cut-off point of 0.7 (Nunnally, 1994). This shows the very good reliability. Convergent validity is assessed by an indicator Average Variance Extracted (AVE). Fornell \& Larcker (1981) suggested the threshold of 0.50 and the AVE here is on par with the suggested criteria. As the table- 2 shows, the average variance extracted AVE is ranging from 0.621 to 0.924 . Composite Reliability is also a scale to determine the measurement fit. It is a more preferred alternative to Cronbach's alpha because Cronbach's alpha may under or overestimate the scale of reliability. AVE is a test used to cover both divergent and convergent validity. AVE tells how much each latent factor has the average communality in the reflective model. As a standard provided by Chin (1998) and Hock \& Ringle (2006: 15), ideally the value of AVE should be greater than 0.5. This above to 0.5 indicates that the factor is explaining more than or equal to half to its respective indicator. The table states all the variables are convincingly above 0.5 apart from Behavioural Intention and Normative behaviour.

\subsection{Discriminant Validity}

Measures of constructs should not be highly related to each other, in fact, not found to be highly correlated to each other. Discriminant Validity should also be less than 1. To test the Discriminant Validity we will determine it through Heterotrait-Monotrait Ratio (HTMT). In Smart PLS SEM 3, if the values are around 0.9. that means discriminant validity has been established between two reflective constructs. Here in table-3 we can see the results are all fine apart from few exceptions where it is marginally higher than 0.9 .

Table 3: Discriminant Validity

\begin{tabular}{|l|c|c|c|c|c|c|c|c|c|}
\hline & ATT & BI & BS & CB & KNW & PER & REP & RO & SUB \\
\hline ATT & & & & & & & & & \\
\hline BI & 0.544 & & & & & & & & \\
\hline BS & 0.406 & 0.534 & & & & & & & \\
\hline CB & 0.451 & 0.606 & 0.945 & & & & & & \\
\hline
\end{tabular}




\begin{tabular}{|l|l|l|l|l|l|l|l|l|l|}
\hline KNW & 0.426 & 0.375 & 1.100 & 0.755 & & & & & \\
\hline PER & 0.779 & 0.715 & 0.346 & 0.437 & 0.621 & & & & \\
\hline REP & 0.432 & 0.535 & 0.916 & 1.162 & 0.803 & 0.627 & & & \\
\hline RO & 0.398 & 0.351 & 0.960 & 0.757 & 0.859 & 0.288 & 0.716 & & \\
\hline SUB & 0.823 & 0.713 & 0.651 & 0.709 & 0.666 & 0.750 & 0.676 & 0.609 & \\
\hline
\end{tabular}

NFI (Normed Fit Index) or Bentler and Bonett Index is between 0 and 1 . Values nearer to 1 is favourable as it indicates the better fitness of this model. The calculation of NFI can be explained as 1 minus $\mathrm{Chi}^{2}$ value of the proposed model divided by the $\mathrm{Chi}^{2}$ values of the null model. All the obtained results are satisfactory for the model to be fit. As for the criteria for SRMR (Standardized Root Mean Square Residual) we take the saturated model. The value obtained is 0.097 which is below 0.1 that fulfils the acceptable criteria.

Table 4: Model Fit Summary

\begin{tabular}{|l|c|c|}
\hline & Saturated Model & Estimated Model \\
\hline SRMR & 0.097 & 0.169 \\
\hline d_ULS & 3.807 & 11.630 \\
\hline d_G & 1.226 & 1.465 \\
\hline & 1722.269 & 2043.994 \\
\hline NFI & 0.720 & 0.668 \\
\hline
\end{tabular}

The table-5 shows the extract of bootstrapping from PLS SEM 3. It has path coefficients with their respective hypothesis model with a t-value critical ratio of each path. As we can see in the table the paths are significant statistically. The table outcomes disclose that 'RO' (Religious Obligation) is a predictor that causes most of the impact on nonusers' attitude towards adoption intention with path coefficient estimates of 0.055 at $\mathrm{p}<0.001$. After that we have cost benefits, Knowledge \& Awareness and then Reputation. Business support creates the least impact among all the other predictors of attitude. If we talk about intentions, we can see a very significant impact of its determinants on the intention of non-users towards Islamic finance adoption. The least impact creator is attitude with 0.185 at $\mathrm{p}>0.05$ and critical ratio 2.153. Subjective norms with path coefficient 0.211 at $p<0.01$ and critical ratio 3.130 are the second most influential determinant. Perceived Behavioural Control is proved to be the main determinant of adoption intention with path coefficient of 0.116 at $p<0.001$ with critical ratio 4.163 is Perceived Behavioural Control.

Table-5:

\begin{tabular}{|l|c|c|c|l|}
\hline & Standard Deviation & Critical ratio (t-value) & P Values & Results \\
\hline ATT -> BI & 0.185 & 2.153 & 0.032 & Supported \\
\hline ATT -> BS & 0.070 & 5.736 & 0.000 & Supported \\
\hline ATT -> CB & 0.063 & 7.121 & 0.000 & Supported \\
\hline ATT -> KNW & 0.060 & 7.009 & 0.000 & Supported \\
\hline ATT -> REP & 0.061 & 6.961 & 0.000 & Supported \\
\hline ATT -> RO & 0.055 & 7.241 & 0.000 & Supported \\
\hline PER -> BI & 0.116 & 4.163 & 0.000 & Supported \\
\hline SUB -> BI & 0.211 & 3.130 & 0.002 & Supported \\
\hline
\end{tabular}


This research pertains to scrutinize the attitude factor that influence the non-adopters of Islamic finance. Attitude, Subjective Norms and Perceived Behaviour Control are variables used under theoretical framework TPB (Theory of Perceived behaviour). Explanatory variables for attitude are Knowledge and awareness, Business Support, Cost benefit, Reputation, Religious obligation. The relationship of variables in this study is created and observed through hypothesis testing. We will discuss each hypothesis one by one and see whether the results obtained are consistent with the antecedent studies or not.

Hypothesis 1: "A positive relationship exists between awareness and knowledge."

The result shows $\mathrm{P}<0.001$ means $(\mathrm{t}> \pm 3.29)$ or $\mathrm{t}=7.009$. The results from Jaffar and Musa (2016) were similar to a likewise study conducted in Malaysia, a Muslim majority country.

Hypothesis 2: "A positive relationship exists between attitude and religion obligation."

The result shows $\mathrm{P}<0.001$ means $\mathrm{t}>3.29$ or $\mathrm{t}>7.241$ that is the highest value among all which shows religion has the highest impact than others on the attitude of non-adopters of Islamic finance.

Hypothesis 3: "A positive relationship exists between attitude and cost benefits."

The result shows $\mathrm{P}<0.001$ means $\mathrm{t}>3.29$ or $\mathrm{t}>7.121$ that turned out to be the second highest explanatory variable for attitude.

Hypothesis 4: "A positive relationship exists between attitude and business support."

The result shows $\mathrm{P}<0.001$ means $\mathrm{t}>3.29$ or $\mathrm{t}>0.5736$. The critical ratio $\mathrm{t}$-value seems to be significant but lowest among the others. The results from Malaysian study Jaffar and Musa (2016) were also very similar. This shows the attitude behaviours of people are very similar regarding the business support provided by Islamic banking of two countries.

Hypothesis 5: "A positive relationship exists between attitude and reputation."

The result shows $\mathrm{P}<0.001$ means $\mathrm{t}>3.29$ or $\mathrm{t}>6.961$. The critical ratio $\mathrm{t}$-value is a bit higher and likewise to the studies like Jaffar and Musa (2016).

Hypothesis 6: "A positive relationship exists between intention to adopt Islamic financing in business and attitude."

The result shows Significant at $\mathrm{p}<0.05(\mathrm{t}> \pm 1.96)$ or $\mathrm{t}=2.153$, attitude seems to be least impactful relationship on intention among the three latent variables.

Hypothesis 7: "A positive relationship exists between intention to adopt Islamic financing in business and subjective norms."

The result shows $\mathrm{P}<0.01$ means $(\mathrm{t}> \pm 2.57)$ or $\mathrm{t}=3.130$.

Hypothesis 8: "A positive relationship exists between intention to adopt Islamic financing in business and perceived behavioural control." 
The result shows $\mathrm{P}<0.001$ means $(\mathrm{t}>3.29)$ or $\mathrm{t}=4.163$. This is the most influence creating latent variable among the three.

\section{Conclusion}

The study outcomes from this endeavour can be helpful to attract halal adopters of Islamic financing in a way that industry practitioners can develop a relevant strategy to entice them. As the results stated above in table 4.7, 'Religious obligation' has the highest critical ratio and hence found to be most influential determinant of attitude. This result is also harmonized with studies Jaffar et al. (2016) and Butt et al. (2011). This shows that the non-user requires the system strictly adhere to Shariah criterion. For example, equal distribution of wealth, halal investments and Riba free banking is very essential for the non-users to embrace the system of Islamic finance. In reference to our research objectives, it is found through this research that there is a need to perpetually increase the level of knowledge and awareness of non-users regarding the principles of Islamic finance and the differences it has with its conventional counterpart. Regarding the strongest predictor of intention, it is 'perceived behavioural control' creating the strongest impact on intention. Perceived strong control on beliefs is very pertinent here because the respondents here are the business owners that have the crucial role in the decision making of their respective businesses. However, it will be better for Islamic financial institutions to provide enough resources and support to entrepreneurs so their adoption intention may become robust. To get the stronger intention for adoption, entrepreneur needs a substantial support from financial institutions. The intention of non-users is heavily influenced by 'Subjective Norms'. It means creating a healthy social interaction or supportive social environment will make people to influence the consumers' behaviour and that will facilitate the promotion of Islamic finance. The findings of this research are restricted to Halal product producers that belong to many groups of products. the researches done in the future can either stretch their domain beyond the Halal lifestyle producers, Halal logistics and Halal food retailers or so they can use any different context of research model to study and validate it generalizability.

\section{References}

Ahmad, N., \& Haron, S. (2002). Perceptions of Malaysian corporate customers towards Islamic banking products and services. International Journal of Islamic Financial Services, 3(4), 13-29 http://iaif.ir/images/khareji/articles/bank/90.pdf

Alam, S. S., Janor, H., Zanariah, C. A. C. W., \& Ahsan, M. N. (2012). Is religiosity an important factor in influencing the intention to undertake Islamic home financing in Klang Valley. World Applied Sciences Journal, 19(7), 1030-1041. https://core.ac.uk/download/pdf/235639897.pdf

Al-Ajmi, J., Hussain, H. A., \& Al-Saleh, N. (2009). Clients of conventional and Islamic banks in Bahrain. International Journal of Social Economics, 36(11), 1086-1112. https://doi.org/10.1108/03068290910992642

Al-Sultan, W. (1999). Financial characteristics of interest-free banks and conventional banks. https://ro.uow.edu.au/theses/1019/

Ajzen, I. (1991). The theory of planned behavior. Organizational Behavior and Human

Decision Processes, 50(2),

179-211.

https://www.tandfonline.com/doi/abs/10.1080/08870446.2011.613995 
Amin, H., Rahman, A. R. A., Sondoh, S. L., \& Hwa, A. M. C. (2011). Determinants of customers' intention to use Islamic personal financing: The case of Malaysian Islamic banks. Journal of Islamic Accounting and Business Research, 2(1), 22-42. https://doi.org/10.1108/17590811111129490

Anderson, J. C., \& Gerbing, D. W. (1988). Structural equation modeling in practice: A review and recommended two-step approach. Psychological Bulletin, 103(3), 411-423. https://psycnet.apa.org/buy/1989-14190-001

Bananuka, J., Mukyala, V., Tumwebaze, Z., Ssekakubo, J., Kasera, M., \& Najjuma, M. S. (2020). The intention to adopt Islamic financing in emerging economies: evidence from Uganda. Journal of Islamic Accounting and Business Research, 11(3), 610-628. https://doi.org/10.1108/JIABR-07-2017-0108

Butt, I., Saleem, N., Ahmed, H., Altaf, M., Jaffer, K., \& Mahmood, J. (2011). Barriers to adoption of Islamic banking in Pakistan. Journal of Islamic Marketing, 2(3), 259-273. https://doi.org/10.1108/17590831111164787

Chin, W. W. (1998). The partial least squares approach to structural equation modeling. Modern methods for business research, 295(2), 295-336.

Davis, F. D., Bagozzi, R. P., \& Warshaw, P. R. (1989). User acceptance of computer technology: A comparison of two theoretical models. Management science, 35(8), 982-1003. https://pubsonline.informs.org/doi/abs/10.1287/mnsc.35.8.982

Dusuki, A. W., \& Abdullah, N. I. (2007). Why do Malaysian customers patronise Islamic banks? International Journal of Bank Marketing, 25(3), 142-160. https://doi.org/10.1108/02652320710739850

Echchabi, A., \& Aziz, H. A. (2012). The relationship between religiosity and customers' adoption of Islamic banking services in Morocco. Arabian Journal of Business and Management Review, 1(10), https://www.arabianjbmr.com/pdfs/OM_VOL_1_(10)/7.pdf

89-94.

Edris, T. A. (1997). Services considered important to business customers and determinants of bank selection in Kuwait: a segmentation analysis. International Journal of Bank Marketing, 15(4), 126-133. https://doi.org/10.1108/02652329710189393

Fishbein, M., \& Ajzen, I. (1977). Belief, attitude, intention, and behavior: An introduction to theory and research. https://philarchive.org/archive/FISBAI

Fishbein, M., Jaccard, J., Davidson, A. R., Ajzen, I., \& Loken, B. (1980). Predicting and understanding family planning behaviors. In Understanding attitudes and predicting social behavior. Prentice Hall. https://nyuscholars.nyu.edu/en/publications/predicting-and-understanding-familyplanning-behaviors

Fornell, C., \& Larcker, D. F. (1981). Structural equation models with unobservable variables and measurement error: Algebra and statistics. https://doi.org/10.1177\%2F002224378101800313

Ghani, B. A. (2013, April 3). The CEO CIMB Islamic Speaker Note in The World Halal Forum and World Halal Research Summit, Kuala Lumpur, (2013). Organized by the Halal Industry Development Corporation. https://www.sciencedirect.com/science/article/pii/S2212567116301186

Jaffar, M. A., \& Musa, R. (2016). Determinants of attitude and intention towards Islamic financing adoption among non-users. Procedia Economics and Finance, 37, 227233.

https://doi.org/10.1016/S2212-5671(16)30118-6 
Jalaluddin, A. (1999). Attitudes of Australian small business firms and financial institutions towards the profit/loss sharing method of finance. University of Wollongong Thesis Collection 1954-2026. https://ro.uow.edu.au/theses/1313/

Lee, K. H., \& Ullah, S. (2011). Customers' attitude toward Islamic banking in Pakistan. International Journal of Islamic and Middle Eastern Finance and Management. 4(2), 131-145. https://doi.org/10.1108/17538391111144524

Mokhlis, S. (2008). Consumer religiosity and the importance of store attributes. The Journal of Human Resource and Adult Learning, 4(2), 122-133. https://www.academia.edu/download/45465989/Consumer_Religiosity_and_the_Im portance 20160508-8844-1gvwoaj.pdf

Montoya-Weiss, M. M. \& Calantone, R.J. (1994). Determinants of new product performance a review and meta-analysis. Journal of Product Innovation Management, 11(5), 397417. https://doi.org/10.1016/0737-6782(94)90029-9

Nunnally, J. C. (1994). Psychometric theory 3E. Tata McGraw-hill education.

Orobia, L. A., Padachi, K., \& Munene, J. C. (2016). Why some small businesses ignore austere working capital management routines. Journal of Accounting in Emerging Economies, 6(2), 94-110. https://doi.org/10.1108/JAEE-08-2013-0039

Sattar, M., Hamza, F., \& Moghar, A. (2020). Adoption of Islamic finance for SMEs and very small enterprises in Morocco. Turkish Economic Review, 6(4), 335-352. http://kspjournals.org/index.php/TER/article/view/1989

Wirtz, J., \& Mattila, A. S. (2003). The effects of consumer expertise on evoked set size and service loyalty. Journal of Services Marketing, 17(7), 649-665. https://doi.org/10.1108/08876040310501223

Yusoff, M. N. H. B., \& Yaacob, M. R. B. (2010). The government business support services in Malaysia: The evolution and challenges in the new economic model. International Journal of Business and Management, 5(9), 60-71. https://www.academia.edu/download/33262446/7308-22838-1-PB.pdf 


\section{Annexures:}

Table-1:

\begin{tabular}{|c|c|c|c|}
\hline Variables & Description & $\begin{array}{c}\text { Number of } \\
\text { Respondents }\end{array}$ & Percentages \\
\hline \multirow[b]{2}{*}{ Religion } & Muslims & 264 & $88 \%$ \\
\hline & Non-Muslims & 36 & $12 \%$ \\
\hline \multirow[b]{2}{*}{ Gender } & Male & 236 & $78.60 \%$ \\
\hline & Female & 64 & $21.40 \%$ \\
\hline \multirow{6}{*}{$\begin{array}{l}\text { Highest Education Level } \\
\text { Attained }\end{array}$} & Primary & 4 & $1.33 \%$ \\
\hline & Secondary & 43 & $14.33 \%$ \\
\hline & Certificate/Diploma & 49 & $16.33 \%$ \\
\hline & Bachelor's degree & 164 & $54.60 \%$ \\
\hline & Masters/PhD & 27 & $9 \%$ \\
\hline & Professional & 13 & $4.30 \%$ \\
\hline \multirow{5}{*}{ Age } & Below 20 years & 4 & $1.33 \%$ \\
\hline & $20-30$ years & 63 & $21 \%$ \\
\hline & $31-40$ years & 79 & $26.33 \%$ \\
\hline & $41-50$ years & 81 & $27 \%$ \\
\hline & Above 50 years & 73 & $24.33 \%$ \\
\hline \multirow{5}{*}{$\begin{array}{l}\text { Annual-Sales Turnover } \\
\text { of Halal Business }\end{array}$} & Less RS. 500,000 & 117 & $39 \%$ \\
\hline & RS. 500,000-1M & 108 & $36.33 \%$ \\
\hline & RS. 1M-10M & 51 & $17 \%$ \\
\hline & RS. 10M-25M & 24 & $8 \%$ \\
\hline & RS. 25M-Above & 10 & $3.33 \%$ \\
\hline \multirow{5}{*}{$\begin{array}{l}\text { Number of Staff } \\
\text { Including Owner in } \\
\text { Halal Business }\end{array}$} & Less than 5 & 57 & $19 \%$ \\
\hline & 5 to less than 10 staff & 69 & $23 \%$ \\
\hline & 10 to less than 50 staff & 83 & $27.66 \%$ \\
\hline & 50 to less than 100 staff & 64 & $21.33 \%$ \\
\hline & 100 to less than 150 staff & 27 & $9 \%$ \\
\hline
\end{tabular}

Table-2: Confirmatory Factor Analysis

\begin{tabular}{|c|c|c|c|c|c|}
\hline & & $\begin{array}{c}\text { Cronbach's } \\
\text { Alpha }\end{array}$ & Rho_A & $\begin{array}{l}\text { Composite } \\
\text { Reliability }\end{array}$ & Composite Reliability \\
\hline ATT & & 0.919 & 0.920 & 0.919 & 0.695 \\
\hline ATT1 & 0.867 & & & & \\
\hline ATT2 & 0.823 & & & & \\
\hline ATT3 & 0.819 & & & & \\
\hline ATT4 & 0.860 & & & & \\
\hline ATT5 & 0.796 & & & & \\
\hline $\mathrm{BI}$ & & 0.705 & 0.777 & 0.739 & 0.496 \\
\hline BI1 & 0.860 & & & & \\
\hline $\mathrm{BI} 2$ & 0.701 & & & & \\
\hline $\mathrm{BI} 3$ & 0.508 & & & & \\
\hline
\end{tabular}


A. I. Shaikh, F. U. Rahim \& T. Taimoor

\begin{tabular}{|c|c|c|c|c|c|}
\hline BS & & 0.656 & 0.687 & 0.668 & 0.506 \\
\hline BS1 & 0.613 & & & & \\
\hline BS2 & 0.797 & & & & \\
\hline $\mathrm{CB}$ & & 0.693 & 0.708 & 0.697 & 0.469 \\
\hline CB1 & 0.505 & & & & \\
\hline CB2 & 0.565 & & & & \\
\hline CB3 & 0.634 & & & & \\
\hline CB4 & 0.706 & & & & \\
\hline KNW & & 0.748 & 0.762 & 0.759 & 0.541 \\
\hline KNW1 & 0.625 & & & & \\
\hline KNW2 & 0.695 & & & & \\
\hline KNW3 & 0.715 & & & & \\
\hline KNW4 & 0.616 & & & & \\
\hline PER & & 0.815 & 0.847 & 0.827 & 0.551 \\
\hline PER1 & 0.780 & & & & \\
\hline PER2 & 0.887 & & & & \\
\hline PER3 & 0.578 & & & & \\
\hline PER4 & 0.689 & & & & \\
\hline REP & & 0.717 & 0.737 & 0.733 & 0.508 \\
\hline REP1 & 0.645 & & & & \\
\hline REP2 & 0.668 & & & & \\
\hline REP3 & 0.685 & & & & \\
\hline REP4 & 0.549 & & & & \\
\hline RO & & 0.720 & 0.744 & 0.726 & 0.504 \\
\hline RO1 & 0.581 & & & & \\
\hline $\mathrm{RO} 2$ & 0.565 & & & & \\
\hline RO3 & 0.787 & & & & \\
\hline RO4 & 0.583 & & & & \\
\hline SUB & & 0.766 & 0.791 & 0.770 & 0.509 \\
\hline SUB1 & 0.738 & & & & \\
\hline SUB2 & 0.724 & & & & \\
\hline SUB3 & 0.487 & & & & \\
\hline SUB4 & 0.486 & & & & \\
\hline SUB5 & 0.710 & & & & \\
\hline
\end{tabular}

